moral responsibility to use that strength." The answer is yes, 1 would, for the corollary to my assertion is that there is a responsibility to use that strength morally. But we know that nations do not always follow moral dictates-- our histories are bloody and cruel-and we need the constraints Falk mentions. Proving that one man's mainstrearn is another man's eddy, Chomsky says the dominant ideology cxempts the U.S. from traditional criticism and presents it only as an international benefactor. Let him try that on in Washington, in the U.N., in embassies in Asia, Europe, Africa, and Latin America. And while I do not agree with Stephen Young that "American power and purpose are no longer trustworthy," it would be foolish to deny that the way in which the United States conducted and ended its role in the war has seriously undercut confidence in America and its foreign policies.

Pace Vietnam and Watergate, the United States is no more exempt from the burdens, templations, and vagaries of history than any great country. But through the confluence of many historical streams it has produced a system of great strengths and valuable ideals that benefits not only its own citizens but those of many other countrics. (I bypass, regretfully, crucial questions concerning the cconomic and political nature of the "system.") John Bennett, John Sheerin, and Franklin Sherman indicate some of the avenues to be explored if we are to best employ these strengths and ideals in a shifting world order.

\section{Peace Witness}

To the Editors: Gordon Zahn's article on "Peace Witness in World War II" (Worldview, February) was magnificent. This is hardly surprising. Dr. Zahn himself was personally a most active witness, and he has done a good deal of scholarly research on the whole subject. However, it may be that he is too modest in assessing the effect of his own heroism and the heroism of his fellow C.O.s.

At least it seems to me that the cli- mate of opinion changed significantly between World War 11 and the Victnam war. I can think of at least three striking facts.

1. Protest against the Vietnam war was unpopular at first, but it was always more or less respectable nevertheless. Those who were quick to disagree with government policy were not automatically written off as traitors as all protestors were during World War'Il. The morality of the war could at least be argued in public

2. The bombing of civitians was frankly approved by the government in World War Il. Harry Truman was proud of Hiroshima. But since then officials have gradually become ashamed of the strategy. When pictures came from Hanoi showing bormbed schools, churches, and residential districts, the official comment was always that a "mistake" had been made. Our planes were sent only against military targets. Too bad if their aim was poor.

3. People were shocked at the Myla massacre and at the official cover-up that followed. Surprisingly enough, public opinion does not now always condone murder, even murder by our own troops

Come on, Dr. Zahn, don't be too modest. Admit that you and your allies had at least something to do with this new point of view.

Paul Hanly Furfey

Emeritus Professor of Sociology Vhsiting Professor of Theology

Catholic University of America

Washington, D.C.

To the Editors: Gordon Zahn is the most significant Catholic spokesman for peace to emerge from the Civilian Public Service camps. His pacifișt witness has endured for the past thirty years. In 1962 Thomas Merton edjed Breakthrough to Peace: Twelve Views on the Threat of Thermonuclear Extermination. Originally Meron de. sired the essays to be written by Catholics, but he was forced to turn to representatives of the broader JudeoChristian tradition because he could find only one Catholic of significant stature who opposed nuclear warfare. That person was Gordon Zahn.

... Peace Witness in World War II" deserves praise, and so does Dr.
Zahn himself. Zahn first became a conscientious objector during World War Il on the theological grounds of the just war. While in the camps he fluctuated between a just war and pacifist rationale. Finally. he became convinced of the pacifist position and was able to reconcile it to Catholicism. It is his personal pacifist witness, strengthened by his Catholic faith, that provides the strength of Zahn's position. It pervades all of his writing on peace. Yet paradoxically, it is this strength that is also his weakness. His position bars the way 10 an analysis of the "links" and "differences" within the American peace movement.

Let me give a few examples. First, Zahn completely dismisses the role of the internationalists during the 1930 's. Granted they, like their irreconcilable companions the isolationists. lost their peace witness once war was declared. But as Charles Chatfield has demonstrated in For Peace and Justice, they are still significant in understanding the American peace movement during the 1930's.

Next, Zaha devotes much space to the traditional peace churches, indicating that he does not mean to ignore the Fellowship of Reconciliation and the War Resister's League. Yet Zahn fails to credit the radical members of these two groups in the camps and prisons with the development of nonviolent resistance-so characteristic of the American scene after World War $l l$ in combating injustices.

And finally, it is the clarity and purity of Zahn's own personal pacafist witness that incapacitates him in dealing with the 1960's. The 1960's were marred by diversity. especially among Catholics. Cicar and pure lines could no longer be drawn between religion and politics, and the old categories of pacifism and just war were inadequate to deal with the range of individual responses - even nonviolent resistance conld not cover adequately the new form of opposition that emerged.

Despite these criticisms, I want to say again that praise is due $\mathrm{Zahn}$ and his labors for peace.

Patricia McNeal

Deparment of History

Indiana University

South Bend, Ind. 